\title{
Pharmacogenetics of adverse cutaneous reactions to lamotrigine
}

\author{
Ana M. Peña-Balderas and Rubén López-Revilla* \\ División de Biología Molecular, Instituto Potosino de Investigación Científica y Tecnológica, San Luis Potosí, S.L.P., Mexico
}

\begin{abstract}
Cutaneous adverse drug reactions include maculopapular exanthema, Stevens-Johnson syndrome, and toxic epidermal necrolysis and are a global public health problem associated with the use of antiepileptic drugs (AEDs). Lamotrigine (LTG) stands out among AEDs because it does not cause sedation and does not affect cognition. Cutaneous adverse reactions (CADRs) to LTG occur in patients carrying certain allele variants of the human leukocyte antigen (HLA) system; although infrequent, they are alarming because they put the life at risk and force discontinuation of the treatment. The fear of neurologists to CADRs to LTG decreases its prescription despite its therapeutic advantages. Here, we review the allele variants of the HLA system that have been associated with CADRs to LTG in Mexican mestizos and other ethnic groups; identification of these variants would serve to select the patients that may be treated with LTG.
\end{abstract}

Key words: Pharmacogenetics. Antiepileptic drugs. Lamotrigine. Cutaneous adverse drug reactions. Human leukocyte antigen system.

\section{Farmacogenética de las reacciones cutáneas adversas a la lamotrigina}

\section{Resumen}

Las reacciones cutáneas adversas a medicamentos incluyen el exantema maculopapular, el síndrome de Stevens-Johnson y la necrólisis epidérmica tóxica y son un problema de salud pública global asociado al uso de fármacos antiepilépticos. La lamotrigina destaca entre los fármacos antiepilépticos porque no causa sedación ni afecta la cognición. Las reacciones cutáneas adversas a lamotrigina ocurren en pacientes que portan ciertas variantes alélicas del sistema HLA; aunque infrecuentes, son alarmantes porque ponen en riesgo la vida y obligan a abandonar el tratamiento. El temor de los neurólogos a las reacciones cutáneas adversas a lamotrigina limita la prescripción del medicamento a pesar de sus ventajas terapéuticas. Aquí revisamos las variantes alélicas del sistema HLA que han sido asociadas a las reacciones cutáneas adversas a lamotrigina en mestizos mexicanos y otros grupos étnicos; la identificación de estas variantes permitiría seleccionar a los pacientes que podrían ser tratados con lamotrigina.

Palabras clave: Farmacogenética. Fármacos antiepilépticos. Lamotrigina. Reacciones cutáneas adversas a medicamentos. Sistema HLA.

\section{Correspondence:}

*Rubén López-Revilla

División de Biología Molecular

Instituto Potosino de Investigación Científica y

Tecnológica

Camino a la Presa San José, 2055 Date of reception: 13-03-2019

C.P. 78216 San Luis Potosí, México Date of acceptance: 25-04-2019

E-mail: rlopez@ipicyt.edu.mx

DOI: 10.24875/RMN.19000051

Available online: 09-08-2019

Rev Mex Neuroci. 2019;20(4):200-206

www.revmexneurociencia.com

1665-5044/C 2019. Academia Mexicana de Neurología A.C. Published by Permanyer México. This is an Open Access article under the terms of the CC BYNC-ND license (http://creativecommons.org/licenses/by-nc-nd/4.0/). 


\section{Introduction}

Antiepileptic drugs (AEDs) are among the most common drugs known to induce cutaneous adverse reactions (cADRs) such as maculopapular exanthema (MPE), Stevens-Johnson syndrome (SJS), and toxic epidermal necrolysis (TEN), with significant morbidity and mortality. The incidence of SJS/TEN is estimated to vary from 1 in 1,000 to 10,000 drug exposures, and its mortality is as high as $35 \%$. The highest rates of adverse drug reactions (ADRs) related to AEDs are caused by lamotrigine (LTG), one of the newer AEDs ${ }^{1}$.

Pharmacogenetics aims to identify the genetic polymorphisms associated with the efficacy and safety of medicines. In this paper, we review the allele variants of the human leukocyte antigen $(\mathrm{HLA})$ system that have been associated with cADRs induced by LTG. Genotyping of the HLA allele variants would, therefore, serve to select the patients that might tolerate and benefit from LTG treatment.

\section{Epilepsy}

Epilepsy is a chronic brain disease caused by an imbalance in the electrical activity of neurons that affects 70 million people in the world and at least five million in Latin America. It is characterized by an enduring predisposition to generate epileptic seizures, and by the neurobiological, cognitive, psychological, and social consequences of this condition. The definition of epilepsy requires the occurrence of at least one epileptic seizure².

Epileptic seizures are considered focal if the electrical activity originates within networks limited to a cerebral hemisphere and affect a limb or a hemibody, generally contralateral. Seizures are generalized if they originate at some point of the cortical and subcortical networks distributed bilaterally; they may affect awareness and sometimes are accompanied by loss of sphincter control with frequencies ranging from less than once a year to several times a day ${ }^{3}$.

Epilepsy has diverse etiologies. The most frequent type is primary or idiopathic epilepsy, in which a genetic or structural cause has not been identified, that affects six out of every 10 patients. Epilepsy from known causes is called secondary or symptomatic epilepsy. It may be due to brain damage from prenatal or perinatal injuries (e.g., asphyxia or trauma during birth, and low birth weight), congenital malformations or genetic alterations with associated brain malformations, severe head trauma, stroke limiting the arrival of oxygen to the

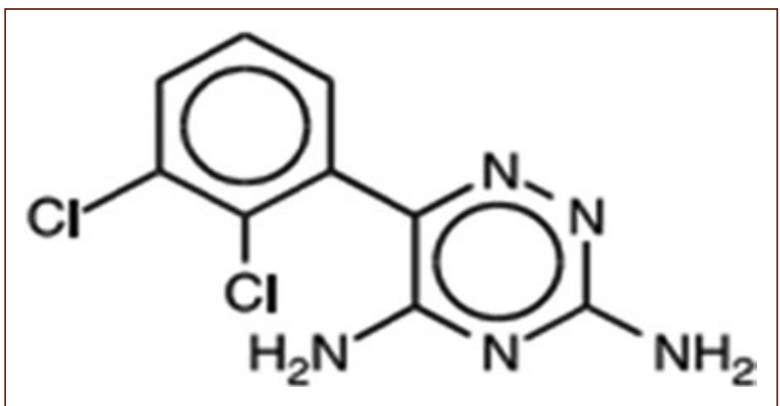

Figure 1. Chemical structure of lamotrigine. PubChem CID: 3878. Chemical name: 3, 5-diamino-6-(2, 3-dichlorophenyl)-1, 2, 4-triazine. Molecular formula: $\mathrm{C}_{9} \mathrm{H}_{7} \mathrm{Cl}_{2} \mathrm{~N}_{5}$. Molecular weight: 256.09.

brain, brain infections (such as meningitis, encephalitis, or neurocysticercosis), some genetic syndromes, and brain tumors ${ }^{4}$.

The treatment of epilepsy is not always easy but accessible with AEDs, whose purpose is to free patients from seizures without side effects and return them to the life of quality without seizures. However, despite numerous attempts to develop safe and innocuous drugs, AEDs have different mechanisms of action, and all can cause adverse or undesirable effects. The appearance of ADRs during the therapy of epilepsy makes it difficult to control seizures, hinders adherence and promotes the suspension of treatment in $25 \%$ of cases with the consequent increase in the cost of therapy and the impact on the life quality of patients ${ }^{5}$.

\section{Lamotrigine}

LTG stands out among the more than 17 AEDs approved for the treatment of focal and generalized epilepsy ${ }^{6,7}$. It was approved by the FDA in 1994 for the treatment of partial seizures and generalized secondary seizures in adults and in 1998 as a complementary treatment for generalized seizures associated with the Lennox-Gastaut syndrome ${ }^{8}$.

LTG is a phenyltriazine (Figure 1) from a group that includes carbamazepine, phenytoin, and valproic acid that potentiate the inhibition mediated by sodium channels ${ }^{9}$. When a neuron is depolarized, sodium channels become inactive. When a neuron is depolarized, its sodium channels are inactivated by a short period (refractory period) during which massive sodium entrance is blocked; this inactivation constitutes a crucial point for the prevention of recurrent discharges into an epileptic potential focus ${ }^{10}$. 
Table 1. Classification of adverse drug reactions and examples of those induced by antiepileptic drugs (adapted from Fricke-Galindo et al. 2018) ${ }^{5}$

\begin{tabular}{|c|c|c|}
\hline Class & Features & Examples of adverse drug reactions \\
\hline A & $\begin{array}{l}\text { Dosage-dependent; excessive pharmacological } \\
\text { response; predictable; reversible; frequent low severity }\end{array}$ & $\begin{array}{l}\text { Dizziness, headache, tremor, drowsiness, insomnia, vertigo, } \\
\text { ataxia, diplopia, depression, hyponatremia, paresthesias, } \\
\text { gastrointestinal disorders }\end{array}$ \\
\hline B & $\begin{array}{l}\text { Not related to the dose or the mechanism of } \\
\text { pharmacological action; related to individual } \\
\text { vulnerability; unpredictable; infrequent; high morbidity } \\
\text { and mortality; reversible }\end{array}$ & $\begin{array}{l}\text { Skin and hypersensitivity reactions (mild maculopapular } \\
\text { exanthema, Stevens-Johnson syndrome, toxic epidermal } \\
\text { necrolysis, etc.), hepatotoxicity, aplastic anemia, } \\
\text { agranulocytosis }\end{array}$ \\
\hline C & $\begin{array}{l}\text { Related to dose and time (dose accumulation); } \\
\text { infrequent; chronicles; most are reversible }\end{array}$ & Weight gain or loss, gingival hyperplasia, visual loss \\
\hline$D$ & $\begin{array}{l}\text { Related to time, usually with prenatal dose and exposure; } \\
\text { infrequent; irreversible }\end{array}$ & Teratogenicity \\
\hline$E$ & Related to the suspension of the medication & $\begin{array}{l}\text { Insomnia, anxiety, and disorders after sudden withdrawal } \\
\text { of benzodiazepines }\end{array}$ \\
\hline $\mathrm{F}$ & $\begin{array}{l}\text { Unexpected therapeutic failure; frequent related to the } \\
\text { dose and interaction of drugs }\end{array}$ & $\begin{array}{l}\text { Decrease in plasma drug concentration by enzymatic } \\
\text { induction of concomitant therapy }\end{array}$ \\
\hline
\end{tabular}
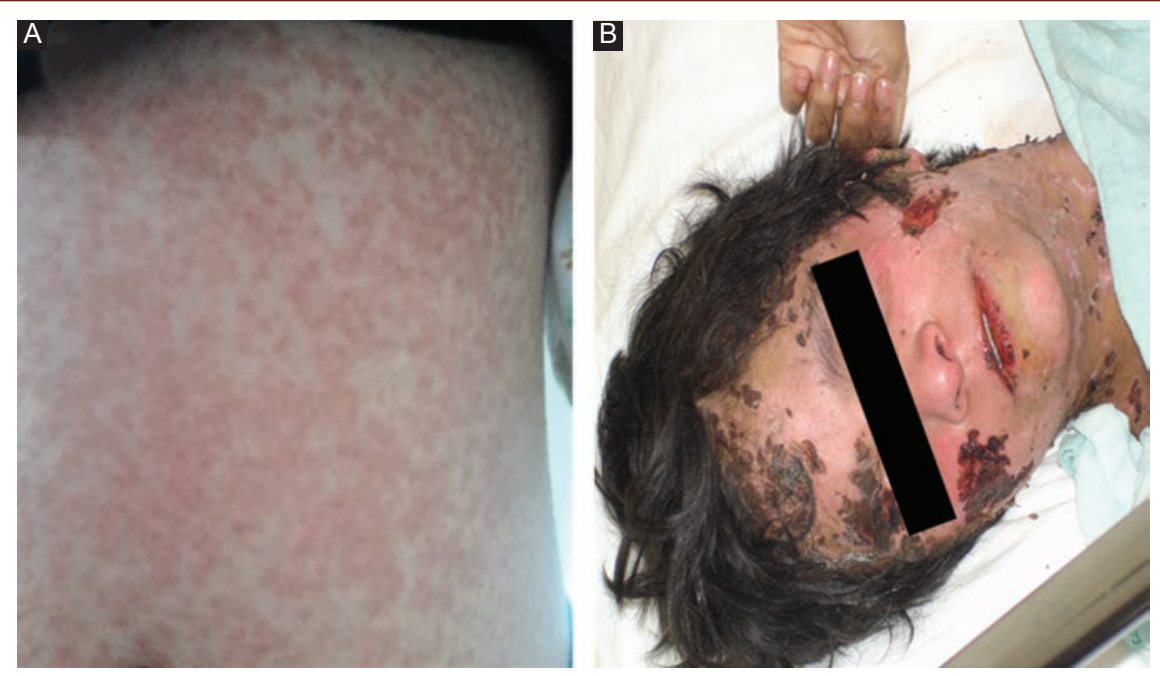

Figure 2. Clinical presentations of adverse drug reactions to medications. A: Maculopapular exanthema. B: Toxic epidermal necrolysis. Photos of these patients were taken and provided to us by Dr. Ildefonso Rodríguez-Leyva.

\section{cADRs to AEDs}

cADRs are defined as "the unintended, harmful response to a drug that occurs with the standard dose used in humans for the prophylaxis, diagnosis, or treatment of a disease or the modification of some function"11.

The cADRs to AEDs represent a serious problem for public health and the individuals who suffer them because their prevalence ranges from $0.7 \%$ to $35 \%$ and they occur in $15 \%$ of hospitalized patients ${ }^{12}$. They are classified according to their mechanisms of pathogenesis (Table 1), the most common being types $\mathrm{A}$ and $\mathrm{B}^{5}$.

Type $B$ reactions are idiosyncratic in nature, less frequent, but more severe than type A reactions; their control requires immediate suspension of the drug or even additional treatment. Type $B$ reactions include severe CADRs whose clinical manifestations range from MPE of varying severity, to life-threatening cutaneous reactions that include the SJS and TEN (Figure 2), with mortalities of up to $5 \%$ for SJS and $30 \%$ for NET. One of their most important sequels is ocular 


\section{Chromosome 6}

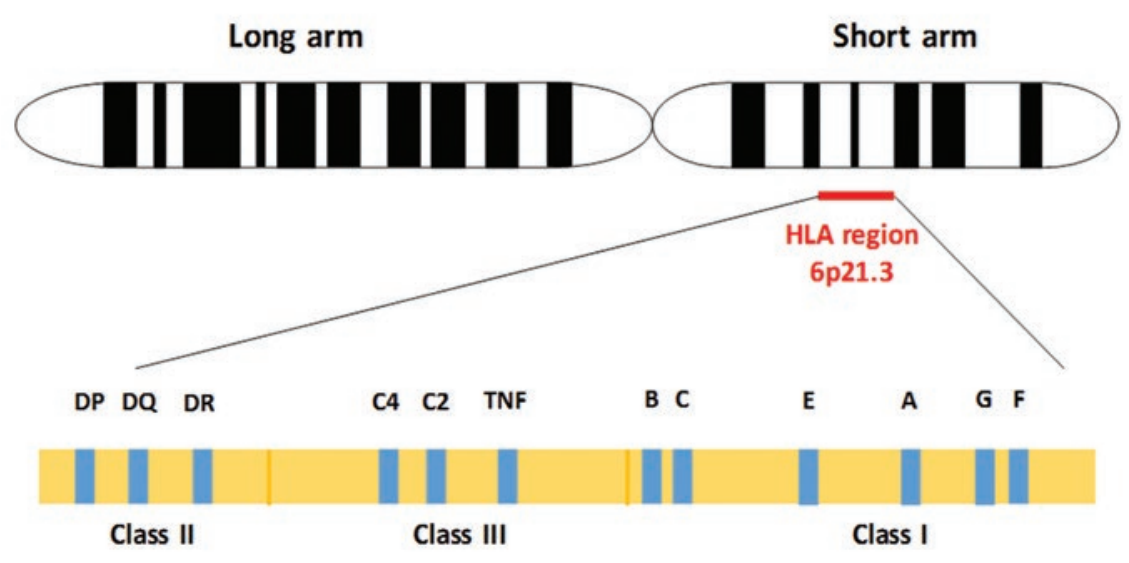

Figure 3. Genetic region of the human major histocompatibility complex. The MHC region is located on the short arm of chromosome 6 (6p21.3) and occupies a DNA segment that extends around $3600 \mathrm{kbp}$. It is a region of highly polymorphic genes that form two separate groups: those of Class I (telomeric) and those of Class II (centromeric). Another group of unrelated genes, called Class III genes, separates the two regions.

because up to $75 \%$ of patients with NET can have complications as severe as blindness ${ }^{5}$.

The highest rates of CADRs related to AEDs are due to LTG, carbamazepine, and phenytoin, drugs structurally related by an aromatic ing $^{12}$.

\section{Pharmacogenetics of the CADRs by LTG}

Pharmacogenetics emerged from various observations of heritable enzyme deficiencies associated with the toxicity of certain drugs in specific groups of individuals. Pharmacogenetic studies consider the association of allele variants of the genes that encode transporters, receptors, and drug metabolizing enzymes with variations in the requirements of dose, efficiency, and development of $\mathrm{ADRs}^{15}$. Knowledge of individual genetics can improve the choice of pharmacotherapy to avoid undesirable effects and adverse reactions in patients ${ }^{13}$.

\section{The HLA system}

The genes of the human major histocompatibility complex (MHC), also called the HLA system, are located in the short arm of chromosome 6 . They encode cell surface molecules specialized in the presentation of antigenic peptides to lymphocytes $T$ that activate critical processes in the generation of the immune response ${ }^{14}$.
Antigen-presenting $\mathrm{MHC}$ molecules are of two main Classes I and II. Class I molecules are encoded in the telomere region, and Class II molecules in the centromere region. Between them is the Class III gene region, or central $\mathrm{MHC}$, of approximately one million base pairs (Figure 3).

The Class I region encodes classical (HLA-A, - B, -C) and non-classical (HLA-E, -F, -G) HLA proteins, whereas the relatively homogeneous Class II region contains the genes encoding HLA-DP, DQ and DR proteins, heterodimers of an alpha and a beta chain that are present in B lymphocytes and monocytes. MHC Class I and Class II regions are so named because they mainly contain HLA genes, whereas the Class III region does not have that defining characteristic because it contains a large number of genes with diverse functions either participating or not in the immune system. MHC gene families have resulted from multiple gene duplication events, so some individual gene pairs such as HLA-B and HLA-C are almost identical ${ }^{15}$.

Some of the risks associated with the HLA system are autoimmune diseases such as rheumatoid arthritis, type 1 diabetes, Graves' disease, multiple sclerosis ${ }^{16}$, and ADRs, among which the cADRs are mediated by dose-independent immune mechanisms associated with allele variants of this system ${ }^{5}$.

The main function of the immune system is to recognize and initiate rapid and specific responses against non-self-antigens. Further reactions occur 


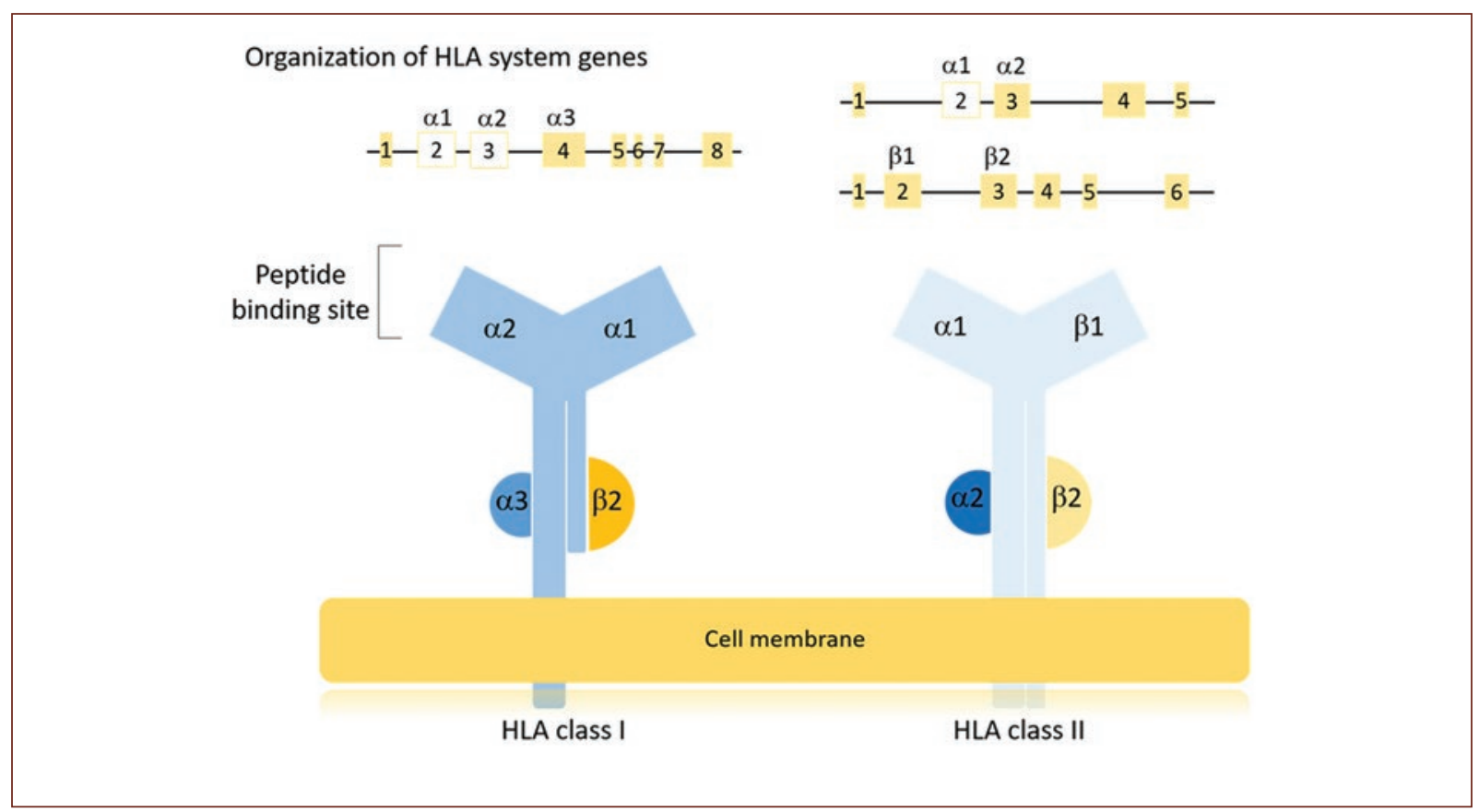

Figure 4. Genes and human leukocyte antigen (HLA) molecules of Class I and Class II. In the scheme of the upper part of the figure, the squares represent the exons, and the lines represent the introns of the HLA system genes. The domains of the HLA molecules encoded by the exons are indicated on the squares; blank squares highlight the exons that contain most of the polymorphisms.

when the system responds inadequately to an adequate stimulus; inadequate responses on cADRs are associated with certain allelic variants of the HLA system.

Although the mechanism of cADRs is not fully defined, two theories have been proposed to explain them: hapten/prohapten and drug/receptor $(p-i)$ immunological interaction ${ }^{5}$. In the first case, it is assumed that, as the drug molecule is too small to induce an immunological response, it acts as a hapten or prohapten that becomes immunogenic by its covalent bond with endogenous proteins to form a hapten-carrier complex. This complex is processed by MHC antigen-presenting cells located in the lymph nodes and other tissues, which stimulate the production of $T$ cells and the consequent clinical manifestations. The $p-i$ theory (pharmacological interactions of drugs with immunological receptors) proposes that some drugs bind directly and reversibly (non-covalently linked) to MHC receptors or to the $T$ cell receptor to stimulate $T$ cells specific for the inducer drug ${ }^{17}$.

Since in the classic HLA system genes the more polymorphic exons encode Class I and Class II molecules (Figure 4), pharmacogenetic studies associated with cADRs by AED have focused on the identification of HLA Class I alleles and to a lesser extent on Class II alleles 5 .

\section{Allele variants of the HLA system associated with cADRs by LTG}

In the decades following isolation of the first HLA gene by molecular cloning (HLA-B7 cDNA), thousands of alleles have been identified whose names and sequences are included in the IMGT/HLA database (http://www.ebi.ac.uk/imgt/hla/index.html), an invaluable tool for all HLA typing systems.

The first attempt at HLA DNA typing involved analysis of restriction fragment length polymorphism, which has many limitations. Development of the polymerase chain reaction (PCR) led to amplification of the polymorphic second and third exons of the HLA Class I and Class II genes and the analysis of polymorphic sequence segments with hybridization sequence-specific oligonucleotide probes. Immobilization of these probes first on membranes and later on spherical particles, together with the first sets of sequence-specific primers (SSP), gave rise to the current set of HLA typing reagents ${ }^{18}$.

SSP-PCR is a fast, efficient, and relatively low-cost method. It has the advantage of distinguishing 
Table 2. Class I HLA alleles and haplotypes associated with cutaneous adverse reactions to lamotrigine in various ethnic groups

\begin{tabular}{|l|l|l|c|c|c|}
\hline Alleles/haplotypes & cADRs & Ethnic group & HLA+/total & $\begin{array}{c}\text { Year of } \\
\text { publication }\end{array}$ & Reference \\
\hline HLA-A*24:02 & cADRs & Norwegians & $10 / 28$ & 2015 & 20 \\
\hline & MPE & Korean & $15 / 21$ & 2015 & 21 \\
\hline HLA-A*30:01 & MPE & Chinese-Han & $6 / 86$ & 2013 & 22 \\
\hline HLA-A*33:03 & MPE & Thai & $3 / 86$ & 2013 & 22 \\
\hline HLA-A*68:01 & cADRs & Europeans & $4 / 44$ & 2009 & 23 \\
\hline HLA-B*44:03 & SJS/TEN & Korean & $3 / 5$ & 2015 & 24 \\
\hline HLA-B*58:01 & CADR & Mixed population & $3 / 44$ & 2009 & 23 \\
\hline HLA-B*35:01:01 & MPE & Mexican mestizos & $6 / 10$ & 2014 & 12 \\
\hline HLA-B*38:01:01 & SJS/TEN & White people & $3 / 3$ & 2017 & 25 \\
\hline HLA-B*57:01:01 & SJS & Mexican mestizos & $1 / 2$ & 2014 & 12 \\
\hline HLA-B*58:01:01 & SJS & Mexican mestizos & $1 / 2$ & 2014 & 12 \\
\hline HLA-A*24:02/C*01:02 & MPE & Korean & $10 / 21$ & 2015 & 21 \\
\hline HLA-B*40:02:01 & SJS & Mexican mestizos & $2 / 4$ & 2014 & 12 \\
\hline HLA-A*02:07:01 & MPE/SJS & Asians & $5 / 15$ & 2017 & 26 \\
\hline HLA-B*44:03:01 & MPE & Asians & $3 / 10$ & 2017 & 26 \\
\hline HLA-A*02:01:01/B*35:01:01/C*04:01:01 & MPE & Mexican mestizos & $5 / 10$ & 2014 & 12 \\
\hline HLA-B*13:02 & MPE & Chinese-Han & $6 / 86$ & 2013 & 22 \\
\hline HLA-B*15:02:01 & MPE/SJS & Asians & $6 / 15$ & 2017 & 26 \\
\hline HLA-A*23:01:01 & SJS & Mexican mestizos & $1 / 4$ & 2014 & 12 \\
\hline A & & \\
\hline
\end{tabular}

cADRs: cutaneous adverse reactions, HLA+/total: number of HLA allele positive subjects in the total number of subjects included, MPE: maculopapular exanthema, SJS: Stevens-Johnson syndrome, TEN: toxic epidermal necrolysis.

several alleles because it detects differences of a single base in the DNA sequence of two alleles, although it cannot detect a new undefined allele unless the change occurs in a location detectable by the primer $^{19}$.

The prevention of cADRs has focused on the HLA locus. Association studies in different populations have described that HLA alleles associated with CADRs are drug-specific and that ethnicity is important. The clinically relevant HLA alleles that have been associated with cADRs induced by LTG are presented in Table 2.

Due to their incidence in cADRs by LTG, the five HLA alleles and the one HLA haplotype most clinically relevant in Mexican mestizos are the following: HLA-A*23:01:01, $-B^{\star} 35: 01: 01,-B^{\star} 40: 02: 01,-B^{\star} 57: 01: 01, B^{\star} 58: 01: 01$, and
HLA-A*02:01:01/B*35:01:01/C*04:01:01 ${ }^{12-20}$. The use of SSP-PCR to identify them would allow to predict the individual risk of CADR and to select the epileptic patients that may be treated with LTG and benefit from it.

\section{Conclusion}

LTG is a valuable AED that does not produce sedation and does not affect cognition. However, its use is limited by the fear of severe cADRs that could compromise the health and lives of the patients. Five alleles and one haplotype of the HLA system have been associated with cADRs by LTG in Mexican mestizos and other ethnic groups. Sequencing of the HLA-A and HLA-B SSP-PCR products would identify the epileptic patients that could tolerate and benefit from LTG treatment. 


\section{Funding}

None.

\section{Conflicts of interest}

None.

\section{References}

1. Shi YW, Min FL, Zhou D, Qin B, Wang J, Hu FY, et al. HLA-A ${ }^{\star} 24: 02$ as a common risk factor for antiepileptic drug-induced cutaneous adverse reactions. Neurology. 2017;88:2183-91.

2. Fisher RS, van Emde Boas W, Blume W, Elger C, Genton P, Lee P, et al. Epileptic seizures and epilepsy: definitions proposed by the international league against epilepsy (ILAE) and the international bureau for epilepsy (IBE). Epilepsia. 2005;46:470-2.

3. Berg AT, Berkovic SF, Brodie MJ, Buchhalter J, Cross JH, van Emde Boas W, et al. Revised terminology and concepts for organization of seizures and epilepsies: report of the ILAE commission on classification and terminology, 2005-2009. Epilepsia. 2010;51:676-85.

4. Shorvon SD. The causes of epilepsy: changing concepts of etiology of epilepsy over the past 150 years. Epilepsia. 2011;52:1033-44.

5. Fricke-Galindo I, Jung-Cook H, LLerena A, López-López M. Pharmacogenetics of adverse reactions to antiepileptic drugs. Neurologia. 2018; 33:165-76.

6. López M, Dorado P, Monroy N, Alonso ME, Jung-Cook H, Machín E, et al. Pharmacogenetics of the antiepileptic drugs phenytoin and lamotrigine. Drug Metabol Drug Interact. 2011;26:5-12.

7. Warshavsky A, Eilam A, Gilad R. Lamotrigine as monotherapy in clinical practice: efficacy of various dosages in epilepsy. Brain Behav. 2016 6:e00419.

8. Motte J, Trevathan E, Arvidsson JF, Barrera MN, Mullens EL, Manasco P et al. Lamotrigine for generalized seizures associated with the lennox-gastaut syndrome. Lamictal lennox-gastaut study group. $\mathrm{N}$ Engl $J$ Med. 1997;337:1807-12.

9. Beattie K, Phadke G, Novakovic J. Lamotrigine. Profiles Drug Subst Excip Relat Methodol. 2012;37:245-85

10. Goldsmith DR, Wagstaff AJ, Ibbotson T, Perry CM. Lamotrigine: a review of its use in bipolar disorder. Drugs. 2003;63:2029-50.

11. World Health Organization. International Drug Monitoring: The Role of National Centers. Geneva: World Health Organization; 1972. Available from: http://www.apps.who.int/iris/bitstream/handle/10665/40968/WHO TRS_498.pdf? sequence=1\&isAllowed=y.

12. Fricke-Galindo I, Martínez-Juárez IE, Monroy-Jaramillo N, Jung-Cook H, Falfán-Valencia $R$, Ortega-Vázquez $A$, et al. HLA-A*02:01:01/-
$B^{*} 35: 01: 01 /-C^{*} 04: 01: 01$ haplotype associated with lamotrigine-induced maculopapular exanthema in Mexican mestizo patients. Pharmacogenomics. 2014;15:1881-91.

13. Kalow W. Pharmacogenetics and pharmacogenomics: origin, status, and the hope for personalized medicine. Pharmacogenomics J. 2006;6:162-5.

14. Cao H, Wu J, Wang $Y$, Jiang $H$, Zhang T, Liu X, et al. An integrated tool to study MHC region: accurate SNV detection and HLA genes typing in human $\mathrm{MHC}$ region using targeted high-throughput sequencing. PLoS One. 2013;8:e69388

15. Varney MD, Castley AS, Haimila K, Saavalainen P. Methods for diagnostic HLA typing in disease association and drug hypersensitivity. Methods Mol Biol, 2012;882:27-46.

16. Gough SC, Simmonds MJ. The HLA region and autoimmune disease: associations and mechanisms of action. Curr Genomics. 2007:8:453-65.

17. Shirzadi M, Thorstensen K, Helde G, Moen T, Brodtkorb E. Do HLA-A markers predict skin-reactions from aromatic antiepileptic drugs in a norwegian population? A case control study. Epilepsy Res. 2015;118:5-9.

18. Erlich H. HLA DNA typing: past, present, and future. Tissue Antigens 2012;80:1-1.

19. Oliveira GC, Ambrosio-Albuquerque EP, Visentainer JE, Oliveira GC, Ambrosio-Albuquerque EP, Visentainer JE. Application of PCR-SSP method for HLA-B*27 identification as an auxiliary tool for diagnosis of ankylosing spondylitis. J Bras Patol Med Lab. 2016;52:217-22.

20. Fricke-Galindo I, LLerena A, López-López M. An update on HLA alleles associated with adverse drug reactions. Drug Metab Pers Ther. 2017;32:73-87.

21. Moon J, Park HK, Chu K, Sunwoo JS, Byun JI, Lim JA, et al. The $\mathrm{HLA}-\mathrm{A}^{*} 2402 / \mathrm{Cw}^{*} 0102$ haplotype is associated with lamotrigine-induced maculopapular eruption in the korean population. Epilepsia. 2015; 56:e161-7.

22. Li LJ, Hu FY, Wu XT, An DM, Yan B, Zhou D, et al. Predictive markers for carbamazepine and lamotrigine-induced maculopapular exanthema in han Chinese. Epilepsy Res. 2013;106:296-300.

23. Kazeem GR, Cox C, Aponte J, Messenheimer J, Brazell C, Nelsen AC, et al. High-resolution HLA genotyping and severe cutaneous adverse reactions in lamotrigine-treated patients. Pharmacogenet Genomics. 2009;19:661-5.

24. Park HJ, Kim SR, Leem DW, Gearing M. Clinical features of and genetic predisposition to drug-induced stevens-johnson syndrome and toxic epidermal necrolysis in a single Korean tertiary institution patients-investigating the relation between the HLA $-B^{\star} 4403$ allele and lamotrigine. Eur J Clin Pharmacol. 2015;71:35-41.

25. Ramírez E, Bellón T, Tong HY, Borobia AM, de Abajo FJ, Lerma V, et al. Significant HLA class I type associations with aromatic antiepileptic drug (AED)-induced SJS/TEN are different from those found for the same AED-induced DRESS in the spanish population. Pharmacol Res. 2017; 115:168-78.

26. Koomdee N, Pratoomwun J, Jantararoungtong T, Theeramoke V, Tassaneeyakul W, Klaewsongkram J, et al. Association of HLA-A and HLA-B alleles with lamotrigine-induced cutaneous adverse drug reactions in the thai population. Front Pharmacol. 2017;8:879. 